\section{Irrigation Schedules and Annual Ryegrass as a Ground Cover to Conserve Water and Control Peach Tree Growth}

\author{
Susan M. Huslig ${ }^{1}$, Michael W. Smith ${ }^{2}$, and Gerald H. Brusewitz ${ }^{3}$ \\ Department of Horticulture and Landscape Architecture, Oklahoma State \\ University, Stillwater, OK 74078
}

Additional index words. Prunus persica, Lolium multiforum

\begin{abstract}
Irrigation schedules were evaluated on 'Cresthaven' peach [Prunus persica (L.) Batsch.] to determine if water application could he reduced or omitted without affecting fruit size or yield. Tensiometers were used to schedule trickle irrigation during 1984-M. Treatments were no irrigation or irrigation when soil pressure potential at a $30-\mathrm{cm}$ depth reached 40 or $60 \mathrm{kPa}$, respectively. When production began in 1986, trees were either irrigated until harvest (1-7 Aug.) or until October. Beginning in 1989, class A pan evaporation was used to schedule irrigation by replacing $60 \%$ of evaporation. Trees were irrigated from budbreak to harvest or October, from beginning of stage III fruit growth until harvest or October, or trees were not irrigated. The irrigation treatments were in factorial combination using sod middles, with annual ryegrass (Lolium multiforum Lam.) seeded under the trees or a sod-herbicide strip. The ryegrass was seeded in October, then killed at the onset of stage III fruit growth. Water application was reduced $32 \%$ to $57 \%$ when irrigation was discontinued after harvest compared to irrigation until October. Irrigation before stage III fruit growth did not affect fruit yield, size, or pruning weights compared to trees irrigated at the onset of stage III fruit growth. Trunk size was increased by irrigation; however, there were no differences in trunk size among irrigation treatments. Irrigation occasionally increased fruit size and yield compared to no irrigation. There were few differences in flower bud density, fruit set, yield, or fruit size among trees with reduced irrigation schedules compared to trees receiving irrigation from budbreak until October. Annual ryegrass decreased shoot growth in 1990 and flower bud density in 1991; however, fruit set was not affected. Annual ryegrass depleted excess soil moisture during the spring in some years, then conserved soil moisture after it was killed. Using sod with annual ryegrass under the trees may be a viable alternative to management with sodherbicide strips.
\end{abstract}

Water is a limited resource in many areas of the world, and management technologies to improve water conservation are necessary. Irrigation scheduling for peach production has been based on available soil moisture (Layne and Tan, 1984; Layne et al., 1986) soil pressurepotential (Chesnessetal., 1992; Hortonet al., 1981; Klein, 1983), and evaporation from a class A pan (Chalmers et al., 1981; Daniell, 1982; Layne and Tan, 1988; Reeder et al., 1979). These-methods provide a sound basis for irrigation requirements to produce healthy growth, high fruit yields, and large fruit size. However, water conservation may be improved if irrigation schedules are developed that provide supplemental water only during critical times of fruit or tree growth, and adjust water application based on environmental conditions. Additionally, certain orchard floor management strategies may improve water conservation.

Received for publication 8 June 1992. Accepted for publication 31 Mar. 1993. Oklahoma Agricultural Experiment Station journal series no. J-6236. The cost of publishing this paper was defrayed in part by the payment of page charges. Under postal regulations, this paper therefore must be hereby marked advertisement solely to indicate this fact.

'Graduate Research Assistant.

${ }^{2}$ Professor of Horticulture.

${ }^{3}$ Professor of Agricultural Engineering.
Most studies have concentrated on improving marketable fruit yield, fruit size, and tree longevity with supplemental irrigation (Daniell, 1982; Feldstein and Childers, 1957, 1965; Hendrickson and Veihmeyer, 1934; Smith and Kenworthy, 1979). However, recent work has addressed water conservation in addition to tree performance. Studies in Australia reported that pear (Pyrus communis L.) size and yield were either not affected or increased by deficit irrigation before the final rapid fruit size increase followed by full irrigation during rapid fruit expansion (Chalmers et al., 1986; Mitchell et al., 1984, 1986, 1989). Reduced early season irrigation also has been used to control shoot growth of pear and peach in the spring without detrimental effects on yield (Chalmers et al., 1981, 1986; Layne and Tan, 1984; Mitchell and Chalmers, 1982; Mitchell et al., 1984, 1986, 1989).

Horton et al. (1981), working in Georgia, found that discontinuing irrigation after harvest $(\approx 4$ Aug.) resulted in fruit yields and size similar to season-long irrigation. Both irrigation until fruit harvest and irrigation throughout the growing season were superior to no irrigation or postharvest irrigation. Discontinuing irrigation after harvest reduced water application by $54 \%$ compared to irrigation throughout the growing season. Larson et al. (1988) reported that, in California, discontinu- ing irrigation of peach after harvest increased return bloom and fruit set compared to postharvest irrigation. In contrast, other studies on apricots (Prunus armeniaca L.) in the desert areas of California indicated that discontinuing irrigation after harvest decreased flower bud formation, fruit set, and yield (Brown, 1953; Uriu, 1964).

Welker and Glenn (1989) showed that young peach trees benefited from herbicidekilled 'Kentucky 31' fescue under the tree canopy. The killed 'Kentucky 31' sod increased soil organic matter and soil microporosity, stabilized soil aggregates, increased water infiltration, and improved tree growth compared to cultivated or herbicide-treated areas under the trees.

The purpose of our study was to evaluate irrigation schedules and soil-management systems that conserve water and control tree growth without adversely affecting fruit size and fruit yield. Water application was regulated initially using tensiometers, and later was scheduled using pan evaporation. Sod with annual ryegrass seeded under the tree canopies or sod with vegetation-free herbicide strips in the tree rows were evaluated to determine their effects on tree performance.

This study was conducted at the Fruit Research Station near Perkins, Okla. The soil is a Teller sandy loam (fine-loamy, mixed, thermic, Udic Argiustolls; Mollisols). 'Cresthaven' trees on Lovell rootstock were planted in 1984, and trickle irrigation was installed with two 3.5-liter $\mathrm{h}^{-1}$ drip emitters per tree (wetted zone per emitter was $\approx 1 \mathrm{~m}$ in diameter). Emitters were placed $45 \mathrm{~cm}$ from each trunk on opposite sides of the trees. In 1986, an additional emitter was installed on opposite sides of each tree, $90 \mathrm{~cm}$ from the trunk. Total water applied was measured with totalizing flow meters.

Trees were trained to a three-scaffold open center. Pest management followed commercial orchard practices, and annual fertilization was based on leaf analysis. Fruit were thinned by hand each year to a density of about four fruit per meter of shoot growth when fruit diameter was $\approx 10 \mathrm{~mm}$. Strips $1.5 \mathrm{~m}$ wide on each side of the tree were maintained vegetation-free with herbicides until 1989, when ground-cover treatments were incorporated into the study.

Irrigation 1984-88. Tensiometers were used to schedule irrigation from 1984 through 1988. Tensiometers were set $30 \mathrm{~cm}$ deep in a triangular pattern $45 \mathrm{~cm}$ from the tree and from the emitters, with one tensiometer for each treatment and replication. The treatments were: 1) no irrigation, 2) irrigation when soil pressure potential reached $40 \mathrm{kPa}$ at a $30-\mathrm{cm}$ depth, and 3) irrigation when soil pressure potential reached $60 \mathrm{kPa}$ at a $30-\mathrm{cm}$ depth. Irrigation was discontinued when the soil pressure potential reached $10 \mathrm{kPa}$ at a $30-\mathrm{cm}$ depth. There were four eight-tree replications per treatment in a randomized complete block design. All treatments were bordered with like treatments.

When fruit production began in 1986, trees were irrigated at the same soil-pressure potentials described earlier, and trees were either 
irrigated throughout the growing season (late March to October) or irrigation was discontinued after harvest ('Cresthaven' harvest is the first week in August). There were four fourtree replications per treatment.

Irrigation 1989-91. In 1989, the treatments were altered, and irrigation was based on evaporation from a class A pan. Sixty percent of the pan evaporation was replaced on alternate days, except during the 1990 growing season when a freeze eliminated fruit production. In $1990,40 \%$ of the pan evaporation was replaced, and irrigation scheduled using fruit growth was based on 1989 data (determination of stage III fruit growth). The formula used to calculate water application was: liters per tree $=$ millimeters of pan evaporation/ $\left(1000 \mathrm{~mm} \cdot \mathrm{m}^{-1}\right) \times$ canopy area (square meters) $\times 1000$ liters $\cdot \mathrm{m}^{-3} \times 0.6$ (Reeder et al., 1979). Rainfall was considered $50 \%$ efficient; i.e., 1 $\mathrm{mm}$ of rainfall $=0.5 \mathrm{~mm}$ of pan evaporation. The irrigation treatments were: 1) no irrigation, 2) irrigation beginning at budbreak and continuing until October, 3) same irrigation schedule as 2, except irrigation was discontinued after harvest, 4) irrigation beginning at stage III fruit growth and continued until October, and 5) same treatment as 4, except irrigation was discontinued after harvest. Stage III fruit growth was determined weekly by measuring the diameter of 20 fruit.

Irrigation treatments were in factorial combination with two orchard floor management systems. One system used a sod (a mixture of crabgrass [Digitaria sanguinalis (L.) Scop., Panicum spp., and brome [Bromus spp.] \} between rows and 1.5-m-wide herbicide strips [2-chloro-4,6-bis(ethylamino)-5-triazine(simazine) plus 3,5-dinitro- $\mathrm{N}_{4}, \mathrm{~N}_{4}$-dipropylsulfanilamide (oryzalin)] on each side of the tree. The second was sod between rows with annual ryegrass hand seeded $\left(100 \mathrm{~kg} \cdot \mathrm{ha}^{-1}\right)$ during October in a $1.5-\mathrm{m}$ strip on each side of the tree. The annual ryegrass was allowed to grow until the beginning of stage III fruit growth, then killed with 1-1'-dimethyl-4,4'bipyridinium ion (paraquat).

Soil moisture was measured weekly with a time domain reflectometer (Soil Moisture Equipment Corp.; Santa Barbara, Calif.). Probes were set $30 \mathrm{~cm}$ deep and $45 \mathrm{~cm}$ from the trunk and emitter in a triangular pattern. Leaf water potential was measured weekly with leaf-cutter psychrometers (J.R.D. Merrill, Logan, Utah) (Smith and Ager, 1988) between dawn and 1000 HR during 1989 and before dawn during 1990 and 1991.

Twenty fruit were collected randomly from each tree for laboratory analysis 1 day before harvest began. Soluble solids concentration (SSC) was determined with a hand-held refractometer, and total solids was determined by oven drying at $80 \mathrm{C}$. Fruit firmness was measured using a penetrometer (Effegi, Afolnsine, Italy) equipped with an 11-mmdiameter probe. Fruit exocarp color was measured on opposite sides of the fruit with a colorimeter (Minolta Cr200, Ramsey, N.J.) using the A (red-green) axis band. Fruit were harvested at 2-day intervals (three to four pickings) when visually judged ripe (South
Table 1. Summary of irrigation and rainfall amounts by year.

\begin{tabular}{|c|c|c|c|c|c|c|c|c|c|}
\hline \multirow[b]{4}{*}{ Year } & \multicolumn{8}{|c|}{ Irrigation timing } & \multirow{4}{*}{$\begin{array}{c}\text { Rainfall } \\
\text { May } \\
\text { to Oct. } \\
\text { (mm) }\end{array}$} \\
\hline & \multicolumn{2}{|c|}{ Budbreak to Oct. } & \multicolumn{2}{|c|}{ Budbreak to harvest } & \multirow{3}{*}{$\begin{array}{c}\text { Budbreak } \\
\text { to Oct. }\end{array}$} & \multirow{3}{*}{$\begin{array}{l}\text { Budbreak } \\
\text { to harvest }\end{array}$} & \multirow{3}{*}{$\begin{array}{c}\text { Stage III } \\
\text { to Oct. }\end{array}$} & \multirow{3}{*}{$\begin{array}{l}\text { Stage III } \\
\text { to harvest }\end{array}$} & \\
\hline & $\mathrm{S}$ & $\overline{\text { ressure }}$ & otential & & & & & & \\
\hline & 40 & 60 & 40 & 60 & & & & & \\
\hline \multicolumn{10}{|c|}{ Water applied (liters/tree) } \\
\hline 1985 & 1549 & 1036 & -.- & --- & --- & ..- & --- & ... & 740 \\
\hline 1986 & 1986 & 1405 & --- & --- & --- & --- & -- & --- & 644 \\
\hline 1987 & 3689 & 2687 & 1682 & 1055 & --- & --- & --- & -- & 648 \\
\hline 1988 & 8447 & 5253 & 5041 & 2823 & --- & $\ldots$ & -.- & --- & 515 \\
\hline 1989 & --- & --- & --- & --- & 454 & 345 & 454 & 345 & 760 \\
\hline 1990 & & --- & --- & --- & 4239 & 2809 & 4239 & 2809 & 425 \\
\hline 1991 & --- & --- & --- & --- & 5345 & 3644 & 4677 & 2977 & 479 \\
\hline
\end{tabular}

Carolina color chip 6) (Delwiche and Baumgardner, 1985), divided into four size groups, and weighed.

Each winter, the trunk diameter was measured $30 \mathrm{~cm}$ above the ground, and the crosssectional area was calculated. During November, flower buds were counted, shoot lengths measured on 20 shoots per tree, and flower buds calculated per meter of shoot growth. Fruit set was determined similarly, before fruit thinning. Beginning in 1988, trees were mechanically hedged in March to $3 \mathrm{~m}$ tall and $3 \mathrm{~m}$ wide, then hand-pruned to improve light penetration. Prunings were collected and weighed from each replication during 1989-91.

Leaf samples were collected during July, from 1989 to 1991, using the middle leaf on current season's growth. Leaves were washed in distilled water followed by a detergent wash (P-free detergent) and two distilled deionized waterrinses. Samples were dried at $80 \mathrm{C}$, ground to pass through an $850-\mu \mathrm{m}$ (20-mesh) screen, and stored in air-tight jars until analysis. Nitrogen was determined using the macro-Kjeldahl method (Horowitz, 1980), P was determined colorimetrically, and other elements were determined by atomic absorption spectroscopy.

There were four four-tree replications per treatment combination. The treatments were arranged in a split-plot design with irrigation treatments as the main plot, and soil management systems as the sub plot. Data were tested using analysis of variance with mean separation by Duncan's multiple range test.

Irrigation 1984-88. Irrigation beginning when the soil pressure potential reached 40 $\mathrm{kPa}$ required $27 \%$ to $38 \%$ more water from budbreak to October than beginning irrigation at $60 \mathrm{kPa}$ (Table 1). During 1987-88, discontinuing irrigation after harvest reduced water application by $40 \%$ to $61 \%$ compared to irrigating until October.

Trunk cross-sectional areas were not affected by irrigation treatments during the first growing season (Fig. 1). In 1986, irrigated trees had larger trunk cross-sectional areas than nonirrigated trees. As tree age increased, differences in trunk cross-sectional areas between the irrigated and nonirrigated treatments increased; however, there were no significant differences in trunk cross-sectional areas among irrigated trees.

Total fruit yields were not affected by irrigation treatments during 1987 or 1988 (data not shown). However, irrigated trees produced more fruit $>70 \mathrm{~mm}$ in diameter than nonirrigated trees in 1988. Fruit firmness was not affected by irrigation treatment (data not shown).

Irrigation 1989-91. Supplemental irriga-

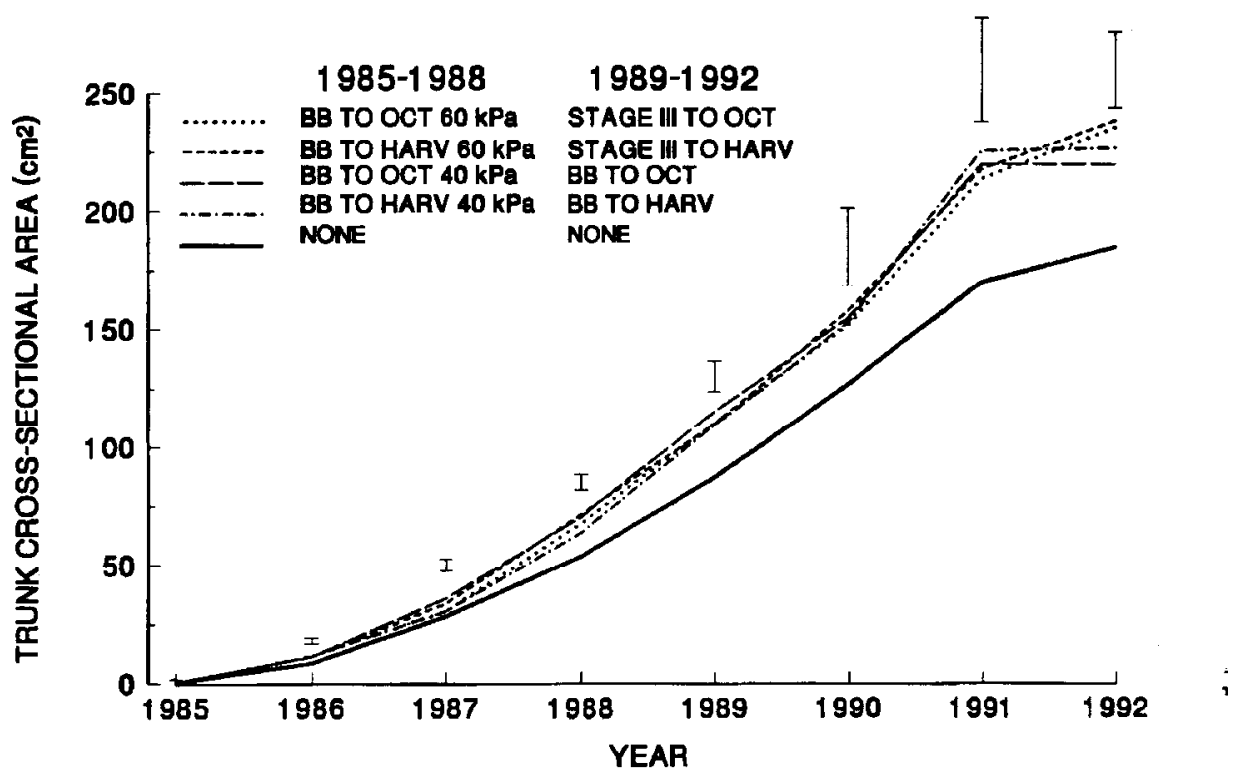

Fig. 1. Influence of irrigation treatments on 'Cresthaven' peach trunk cross-sectional area from 1985 to 1992, measured $30 \mathrm{~cm}$ ahnve the ground. Vertical bars indicate least significant difference, $P=0.05$, and $\mathrm{BB}$ is budbreak. 

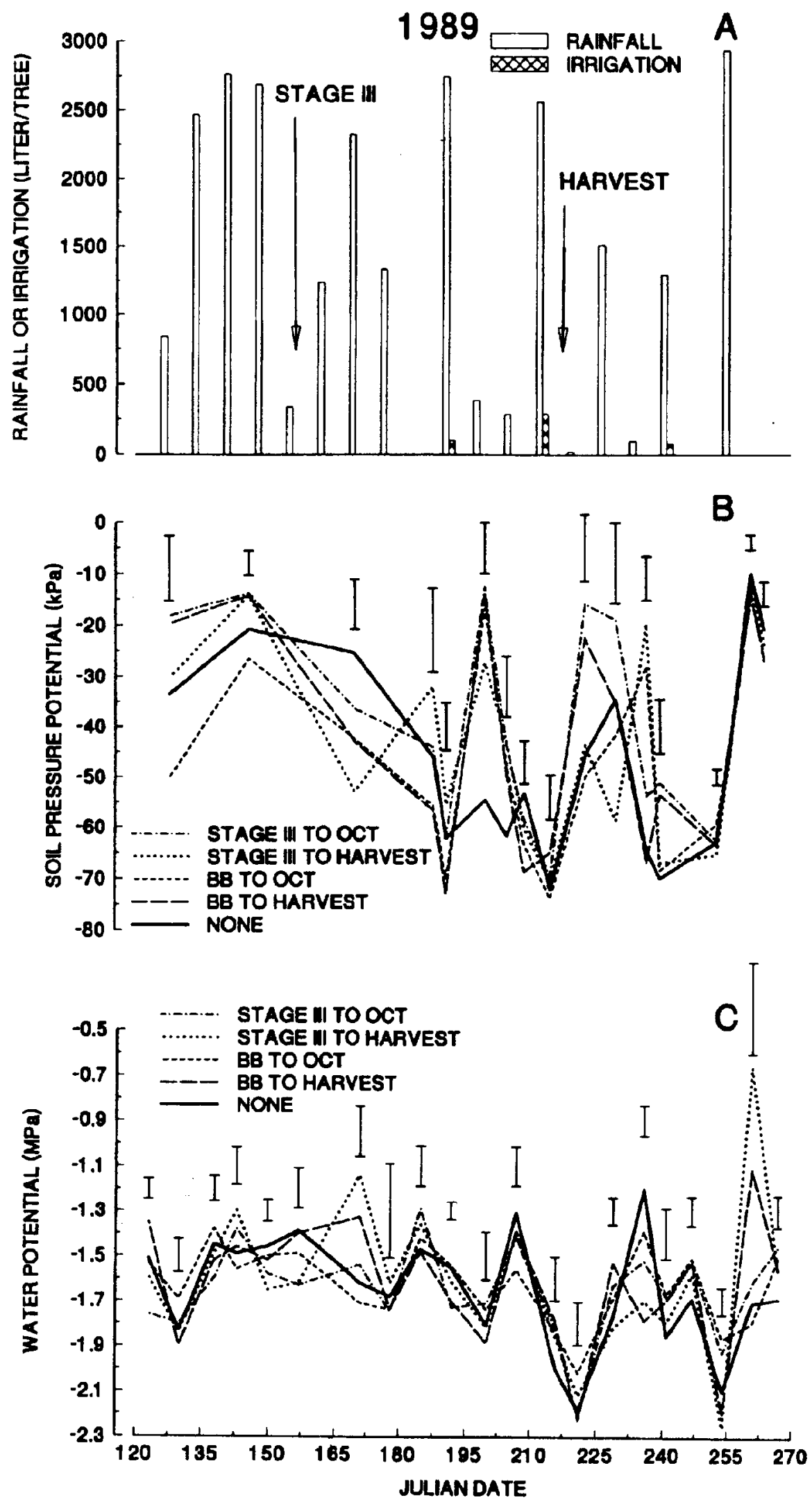

Fig. 2. Irrigation application and rainfall amounts (A), soil pressure potential in soil under various irrigation treatments $(\mathbf{B})$, and early morning leaf water potential among irrigation treatments $(\mathbf{C})$ measured during 1989 from 1 May (Julian date 120) to 1 Oct. (Julian date 270) on 'Cresthaven' peaches. Rainfall was converted to liters per tree using (millimeters of rainfall/1000 mm per meter $\times 10,000 \mathrm{~m}^{2} \cdot \mathrm{ha}^{-1} \times 1000$ liter $\left.\cdot \mathrm{m}^{-3}\right) /($ trees/hectare). Vertical bars indicate $\mathrm{SE}$, and BB is budbreak. tion rates increased with tree age until 1989, when rainfall from May through October was above average (Table 1). Irrigation was applied only three times during the 1989 growing season (Fig. 2A), and there were few differences in soil pressure potential or leaf water potential among irrigation treatments (Fig. 2 B and C).

There was no crop in 1990, and $40 \%$ rather than $60 \%$ of the evaporation from the class $\mathrm{A}$ pan was replaced by irrigation. Irrigation based on fruit development for 1990 used fruit development data obtained during 1989. Based on pan evaporation rates and rainfall, trees were not irrigated in 1990 until stage III fruit growth would have begun (Fig. 3A). Soil moisture was lower in nonirrigated plots than irrigated plots during most of the assumed stage III fruit growth (Fig. 3B); however, there were few differences in leaf water potential among irrigation treatments (Fig. 3C). Soil moisture dropped to levels near the nonirrigated treatment when irrigation was discontinued after the assumed normal harvest time. However, on the treatments in which irrigation was continued until October, soil moisture was usually above nonirrigated values (Fig. 3B). No consistent differences in leaf water potential were observed during the 1990 growing season (Fig. 3C).

During 1991, irrigation replaced $60 \%$ of pan evaporation because there was a full crop. Although rainfall was higher during Spring 1991 (Fig. 4A) than 1990 (Fig. 3A), trees were irrigated three times before the beginning of stage III fruit growth. Higher evaporation rates during 1991 dictated the water applications; however, rainfall frequently occurred soon after the early season irrigations in 1991, negating their value. There were few differences in soil moisture before stage III fruit growth (Fig. 4B). During stage III, soil moisture usually was higher in irrigated than nonirrigated treatments. After harvest, the plots continuing to receive irrigation usually had a higher soil moisture content than nonirrigated plots, until rainfall in September increased the soil moisture of all plots. There were few significant differences in leaf water potential among irrigation treatments during 1991 (Fig. 4C).

There were no significant interactions between irrigation and ground-cover treatments. Therefore, main-effect means are presented and discussed. In 1989, trees irrigated from budbreak until October or from stage III fruit growth until October produced more total yield and fruit that were 64 to $70 \mathrm{~mm}$ in diameter than the nonirrigated trees (Table 2). Fruit weights in the other size categories were not affected. In 1991, trees irrigated from budbreak until harvest produced more fruit 64 to $70 \mathrm{~mm}$ in diameter than nonirrigated trees, but total yield and fruit weight in the other size categories were not affected. There were no significant differences in fruit firmness, fruit color, SSC, or total solids concentration among irrigation treatments during 1991 (data not shown).

Flower bud density was not affected by irrigation treatments during 1989-92, and fruit set was not affected by irrigation treatments 

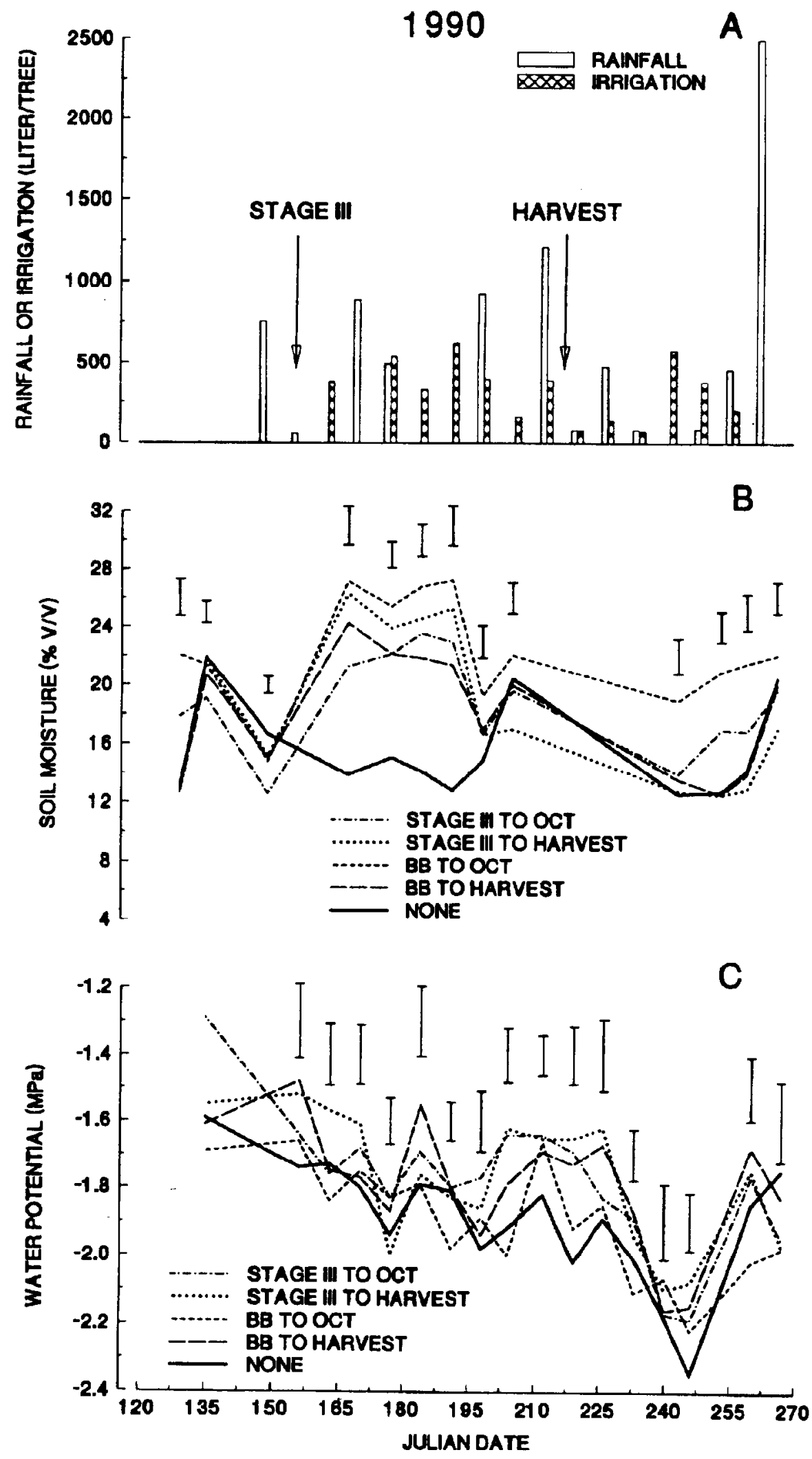

Fig. 3. Irrigation application and rainfall amounts $(\mathbf{A})$, soil moisture of irrigation treatments $(\mathbf{B})$, and predawn leaf water potential among irrigation treatments (C) measured during 1990 from 1 May (Julian date 120) to 1 Oct. (Julian date 270) on 'Cresthaven' peaches. Rainfall was converted to liters per tree using (millimeters of rainfall/1000 mm per meter $\left.\times 10,000 \mathrm{~m}^{2} \cdot \mathrm{ha}^{-1} \times 1000 \mathrm{liter} \cdot \mathrm{m}^{-3}\right) /($ trees/hectare). Vertical bars indicate SE, and BB is budbreak. during 1989 or 1991 (data not shown). In 1991, there was a slight increase in the number of fruit derived from multiple carpels on nonirrigated trees $(1.3 \mathrm{fruit} / \mathrm{m})$ compared to irrigated trees $(0.9$ fruit $/ \mathrm{m})$; however, the differences were not significant.

Irrigation treatments did not affect actual pruning weights or adjusted pruning weights (pruning weight per trunk cross-sectional area) during 1989-91 (data not shown). Leaf elemental concentrations of $\mathrm{N}, \mathrm{P}, \mathrm{K}, \mathrm{Ca}, \mathrm{Mg}, \mathrm{Zn}$, $\mathrm{Fe}$, and $\mathrm{Mn}$ were not affected by irrigation treatments during 1989-91 (data not shown).

Soil moisture generally was not affected by soil management during 1989 (data not shown) due to unusually high rainfall. During 1990, soil moisture was lower in the annual ryegrasssod plots than in the herbicide-sod plots until the ryegrass was killed at the beginning of stage III fruit growth (data not shown); soil moisture was then higher in the killed annual ryegrass-sod plots. This difference suggests either that water infiltration was greater in the killed annual ryegrass-sod plots or that it acted as a mulch, decreasing water loss from the soil. High rainfall amounts and unusually cool weather beginning 22 July 1990 stimulated annual ryegrass germination, depleting soil moisture the remainder of the season, compared to the herbicide-sod plots. Normally, annual ryegrass seed does not germinate until late September or October.

In 1991, soil moisture was lower in the annual ryegrass-sod plots until the ryegrass was killed at the beginning of stage III fruit growth (data not shown). Soil moisture in the killed annual ryegrass-sod plots was then higher until rainfall during September increased the soil moisture in both treatment areas.

Floor management of the two treatment areas did not affect total relative fruit yield during 1989 or 1991 (Table 3). In 1989, trees with annual ryegrass sod produced fewer small peaches (57 to $63 \mathrm{~mm}$ in diameter). In 1991, trees with annual ryegrass sod produced more peaches $\geq 70 \mathrm{~mm}$ in diameter and fewer peaches with diameters $163 \mathrm{~mm}$ than those in herbicide-sod treatments. Fruit firmness, fruit color, SSC, and total solids concentration were not affected by ground-cover treatments (data not shown). Soil management treatments also did not affect pruning weights in 1989 and 1991; however, in 1990, annual ryegrass sod was associated with decreased pruning weights.

Flower bud density was not affected by ground-cover treatments, except in 1991 (data not shown), when trees with annual ryegrasssod had a lower density. However, fruit set was not affected during any year by soil management.

The soil management system also did not affect leaf elemental concentrations and leaf water potentials during 1989-91 (data not shown).

Others have reported that irrigating young trees increased growth; thus, trees filled their allotted space more quickly, providing the potential for higher, earlier-yield returns (Chesness et al., 1992). In contrast, the total tree yields during the 'first 2 years of production (1987 and 1988) in this study were not 

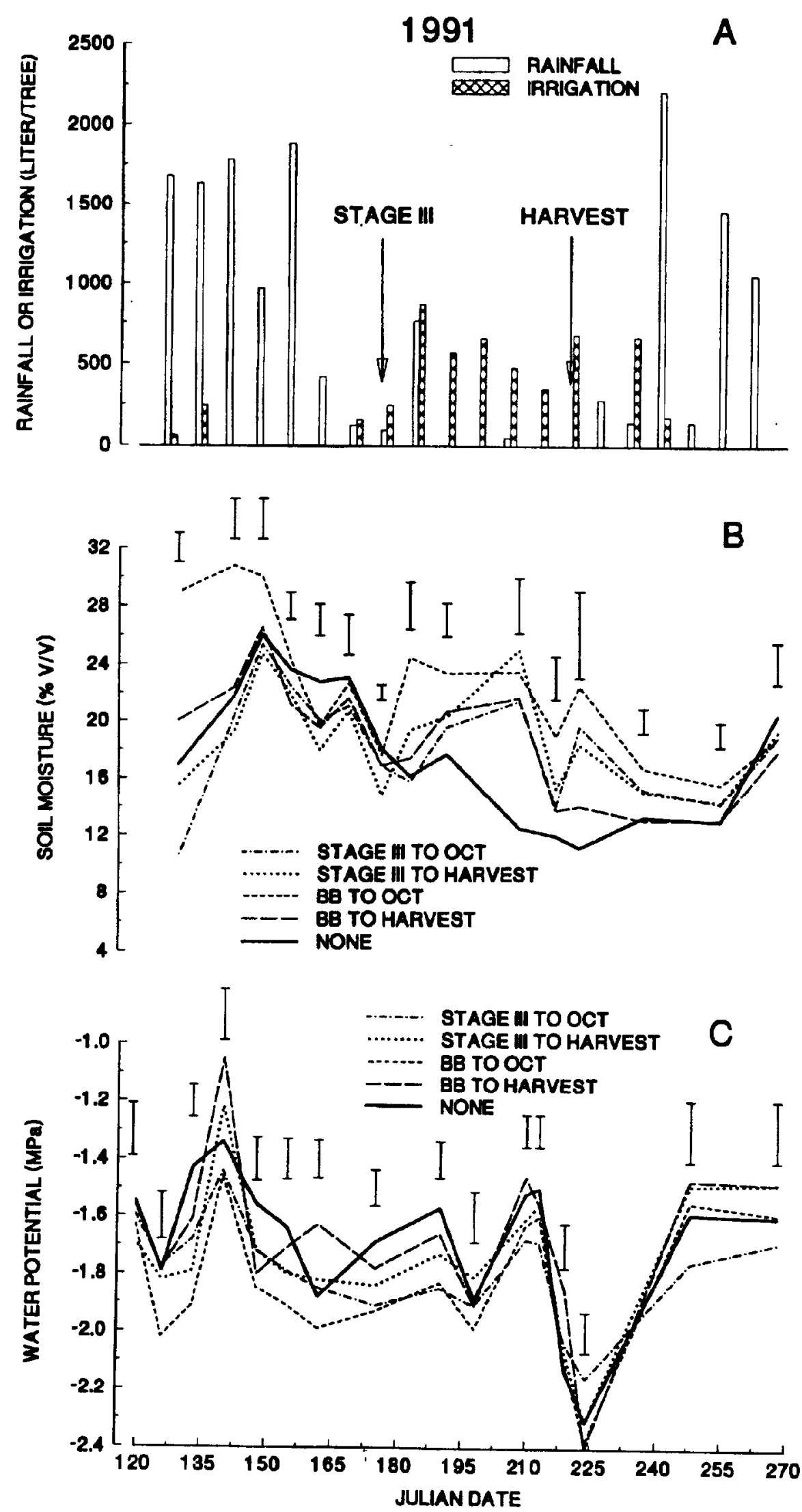

Fig. 4. Irrigation application and rainfall amounts (A), soil moisture in irrigation treatments $(\mathbf{B})$, and predawn leaf water potential among irrigation treatments (C) measured during 1991 from 1 May (Julian date 120) to 1 Oct. (Julian date 270) on 'Cresthaven' peaches. Rainfall was converted to liters per tree using (millimeters of rainfall $/ 1000 \mathrm{~mm}$ per meter $\times 10,000 \mathrm{~m}^{2} \cdot \mathrm{ha}^{-1} \times 1000 \mathrm{liter} \cdot \mathrm{m}^{-3}$ )/(trees/hectare). Vertical bars indicate $S E$, and $B B$ is budbreak.

affected by irrigation treatment. Trunk crosssectional area was not affected by irrigation treatment the first year (1985), and increased only slightly by irrigation in 1986 (Fall 1986 trunk cross-sectional areas would represent the 1987 bearing surface) (Fig. 1). These data indicate that when spring soil moisture was abundant, irrigation had little impact on how rapidly trees filled their allotted space; thus, the yield of 3- and 4-year-old trees was not affected.

Trees were only irrigated before stage III fruit growth during 1 year of this study. Postharvest irrigation did not improve tree performance and increased water application by $32 \%$ to $57 \%$. Total yields per tree, after trees had filled their allotted area, usually were not affected by irrigation; however, fruit size was increased occasionally by irrigation. These data indicated that irrigation was only beneficial during some years under this study's conditions; i.e., in an area that commonly receives rainfall during the summer. Irrigation before stage III fruit growth or after harvest did not benefit fruit size or yield.

After being killed at stage III fruit growth, annual ryegrass improved soil moisture retention either by acting as a mulch or by increasing water infiltration during 1990 and 1991. Other studies have indicated that a grass cover or mulch increased rainfall infiltration, thus increasing soil moisture (Havis, 1941; Havis and Gourley, 1937; Rogers et al., 1948; Welker and Glenn, 1989). We observed little weed growth in the annual ryegrass plots after the ground cover was killed. The dense debris from the annual ryegrass was apparently sufficient to inhibit weeds. Leaf elemental concentrations were not affected by soil management, indicating that tree competition with annual ryegrass was minimal, and no additional $\mathrm{N}$ would be required with this management system, as suggested by other studies using a permanent competitive cover (Bould and Jarrett, 1962; Goode and Hyrycz, 1976; Rogers et al., 1948).

In conclusion, trees with annual ryegrass sod produced more large fruit and fewer small fruit than trees with the herbicide-sod treatment. Yield was not affected by either soil management system. An annual ryegrass ground cover under the trees, which is killed at the onset of stage III fruit growth and which has sod row middles, may be a viable alternative to the traditional pre-emergent herbicidesod floor management system and merits additional evaluation under environmental conditions different from ours.

\section{Literature Cited}

Bould, C. and R.M. Jarrett. 1962. The effects of cover crops and NPK fertilizers on growth, crop yield and leaf nutrient status of young dessert apples. J. Hort. Sci. 3758-82.

Brown, D.S. 1953. The effects of irrigation on flower bud development and fruiting in the apricot. Proc. Amer. Soc. Hort. Sci. 61:119124.

Chalmers, D.J., G. Burge,. P.H. Jerie, and P.D. Mitchell. 1986. The mechanism of regulation of 'Bartlett' pear fruit and vegetative growth by 
Table 2. Influence of irrigation treatments on 'Cresthaven' fruit size and yield.

\begin{tabular}{|c|c|c|c|c|c|}
\hline \multirow{3}{*}{$\begin{array}{l}\text { Irrigation } \\
\text { treatment }\end{array}$} & \multicolumn{5}{|c|}{ Yield $(\mathrm{kg} /$ tree $)$} \\
\hline & \multicolumn{4}{|c|}{ Fruit diam (mm) } & \multirow{2}{*}{$\begin{array}{l}\text { Total } \\
\text { yield }\end{array}$} \\
\hline & $>70$ & 64 to 70 & 57 to 63 & $<57$ & \\
\hline \multicolumn{6}{|c|}{1989} \\
\hline None & $30.9 \mathrm{a}^{\mathrm{z}}$ & $36.0 \mathrm{~b}$ & $26.0 \mathrm{a}$ & $13.0 \mathrm{a}$ & $106 \mathrm{~b}$ \\
\hline Budbreak to October & $44.2 \mathrm{a}$ & $45.0 \mathrm{a}$ & $30.2 \mathrm{a}$ & $11.8 \mathrm{a}$ & $131 \mathrm{a}$ \\
\hline Budbreak to harvest & $46.2 \mathrm{a}$ & $41.6 \mathrm{ab}$ & $24.6 \mathrm{a}$ & $10.7 \mathrm{a}$ & $123 \mathrm{ab}$ \\
\hline Stage III to October & $48.7 \mathrm{a}$ & $44.9 \mathrm{a}$ & $29.1 \mathrm{a}$ & $11.6 \mathrm{a}$ & $134 \mathrm{a}$ \\
\hline Stage III to harvest & $42.0 \mathrm{a}$ & $40.3 \mathrm{ab}$ & $27.3 \mathrm{a}$ & $10.1 \mathrm{a}$ & $120 \mathrm{ab}$ \\
\hline \multicolumn{6}{|c|}{1991} \\
\hline None & $4.1 \mathrm{a}$ & $21.4 \mathrm{~b}$ & $66.0 \mathrm{a}$ & $9.7 \mathrm{a}$ & $101 \mathrm{a}$ \\
\hline Budbreak to October & $11.7 \mathrm{a}$ & $25.9 \mathrm{ab}$ & $64.3 \mathrm{a}$ & $6.6 \mathrm{a}$ & $108 \mathrm{a}$ \\
\hline Budbreak to harvest & $11.5 \mathrm{a}$ & $35.2 \mathrm{a}$ & $65.4 \mathrm{a}$ & $6.4 \mathrm{a}$ & $118 \mathrm{a}$ \\
\hline Stage III to October & $10.7 \mathrm{a}$ & $25.9 \mathrm{ab}$ & $59.8 \mathrm{a}$ & $8.2 \mathrm{a}$ & $105 \mathrm{a}$ \\
\hline Stage III to harvest & $13.2 \mathrm{a}$ & $27.1 \mathrm{ab}$ & $53.5 \mathrm{a}$ & $5.3 \mathrm{a}$ & $100 \mathrm{a}$ \\
\hline
\end{tabular}

${ }^{2}$ Mean separation within column and year by Duncan's multiple range test, $P \leq 0.05$.

Table 3. Influence of soil management treatments on 'Cresthaven' peach fruit size and yield.

\begin{tabular}{|c|c|c|c|c|c|}
\hline \multirow{3}{*}{$\begin{array}{l}\text { Soil } \\
\text { management }\end{array}$} & \multicolumn{4}{|c|}{ Yield (kg/tree) } & \multirow{3}{*}{$\begin{array}{l}\text { Total } \\
\text { yield } \\
\end{array}$} \\
\hline & \multicolumn{4}{|c|}{ Fruit diam (mm) } & \\
\hline & $>70$ & 64 to 70 & 57 to 63 & $<57$ & \\
\hline & & 1989 & & & \\
\hline Herbicide sod & $40.4 a^{z}$ & $44.0 \mathrm{a}$ & $30.7 \mathrm{a}$ & $12.5 \mathrm{a}$ & $127.6 \mathrm{a}$ \\
\hline Ryegrass sod & $44.4 \mathrm{a}$ & $39.1 \mathrm{a}$ & $24.1 \mathrm{~b}$ & $10.3 \mathrm{a}$ & $118.0 \mathrm{a}$ \\
\hline & & 1991 & & & \\
\hline Herbicide sod & $6.5 \mathrm{~b}$ & $24.6 \mathrm{a}$ & $72.0 \mathrm{a}$ & $9.1 \mathrm{a}$ & $112.2 \mathrm{a}$ \\
\hline Ryegrass sod & $14.4 \mathrm{a}$ & $30.0 \mathrm{a}$ & $51.1 \mathrm{~b}$ & $5.1 \mathrm{~b}$ & $100.6 \mathrm{a}$ \\
\hline
\end{tabular}

${ }^{\mathrm{z}}$ Mean separation within column and year by Fisher's F test, $P \leq 0.05$.

irrigation withholding and regulated deficit irrigation. J. Amer. Soc. Hort. Sci. 111:904-907.

Chalmers, D.J., P.D. Mitchell, and L. van Heek.

198 1. Control of peach tree growth and productivity by regulated water supply, tree density, and summer pruning. J. Amer. Soc. Hort. Sci. 106:307-312.

Chesness, J., M. Rieger, and S. Myers. 1992. Trickle irrigated wetted area for peach trees. Georgia Agr. Expt. Sta. Res. Rpt. 607.

Daniell, J.W. 1982. Effect of trickle irrigation on the growth and yield of 'Loring' peach trees. J. Hort. Sci. 57:393-399.

Delwiche, M.J. and R.A. Baumgardner. 1985. Ground color as a peach maturity index. J. Amer. Soc. Hort. Sci. 110:53-57.

Feldstein, J. and N.F. Childers. 1957. Effect of irrigation on fruit size and yield of peaches in Pennsylvania. Proc. Amer. Soc. Hort. Sci. 69:126-130.

Feldstein, J. and N.F. Childers. 1965. Effects of irrigation on peaches in Pennsylvania. Proc. Amer. Soc. Hort. Sci. 87:145-153.

Goode, J.E. and K.J. Hyrycz. 1976. The effect of nitrogen on young, newly-planted apple rootstocks in the presence and absence of grass competition. J. Hort. Sci. 51:321-327.

Havis, L. 1941. Relation between soil organic matter and available moisture under different orchard cultural systems. Proc. Amer. Soc. Hort. Sci. 38:32-35

Havis, L. and J.H. Gourley. 1937. Soil organic matter and porosity of a orchard soil under different cultural systems. Soil Sci. 43:413-420.

Hendrickson, A.H. and F.J. Veihmeyer. 1934. Size of peaches as affected by soil moisture. Proc. Amer. Soc. Hort. Sci. 32:284-286.

Horowitz, W. 1980. Fertilizers, p. 15, section 205. In: S. Williams (ed.). Official methods of analysis of the Association of Analytical Chemists. 13th ed. Assn. Official Analytical Chemists, Washington, D.C.

Horton, B.D., E.J. Wehunt, J.H. Edwards, R.R. Bruce, and J.L. Chesness. 1981. The effects of drip irrigation and soil fumigation on 'Redglobe' peach yields and growth. J. Amer. Soc. Hort. Sci. 106:438-443.

Klein, I. 1983. Drip irrigation based on soil matrix potential conserves water in peach and grape HortScience 18:942-944.

Larson, K.D., T.M. DeJong, and R.S. Johnson. 1988. Physiological and growth responses of mature peach trees to postharvest water stress. J. Amer. Soc. Hort. Sci. 113:296-300.

Layne, R.E.C. and C.S. Tan. 1984. Long-term influence of irrigation and tree density on growth, survival and production of peach. J. Amer. Soc. Hort. Sci. 109:795-799.

Layne, R.E.C. and C.S. Tan. 1988. Influence of cultivars, ground covers and trickle irrigation on early growth, yield, and cold hardiness of peaches in fox sand. J. Amer. Soc. Hort. Sci. 113:518525.

Layne, R.E.C., C.S. Tan, and R.L. Perry. 1986. Characterization of peach roots in fox sand as influenced by sprinkler irrigation and tree density. J. Amer. Soc. Hort Sci. 111:670-677.

Mitchell, P.D. and D.J. Chalmers. 1982. The effect of reduced water supply on peach tree growth and yields. J. Amer. Soc. Hort. Sci. 107:853856.

Mitchell, P.D., D.J. Chalmers, P.H. Jerie, and G. Burge. 1986. The use of initial withholding of irrigation and tree spacing to enhance the effect of regulated deficit irrigation on pear trees. J. Amer. Soc. Hort. Sci. 111:858-861.

Mitchell, P.D., P.H. Jerie, and D.J. Chalmers. 1984. The effects of regulated water deficits on pear tree growth, flowering, fruit growth and yield. J. Amer. Soc. Hort. Sci. 109:604-606.

Mitchell, P.D., B. van den Ende, P.H. Jerie, and D.J. Chalmers. 1989. Responses of 'Bartlett' pear to withholding irrigation, regulated deficit irrigation and tree spacing. J. Amer. Soc. Hort. Sci. 114:15-19.

Reeder, B.D., J.S. Newman, and J.W. Worthington. 1979. Effect of trickle irrigation on peach trees. HortScience. 14:36-37.

Rogers, W.S., T.H. Raptopoulos, and D.W.P. Greenham. 1948. Covercrops for fruit plantations. IV. Long-term leys and permanent swards. J. Hort. Sci. 24:228-270.

Smith, M.W. and P.L. Ager. 1988. Effects of soil flooding on leaf gas exchange of seedling pecan trees. HortScience. 23:370-372.

Smith, M.W. and A.L. Kenworthy. 1979. The response of fruit trees in Michigan to trickle irrigation. Soil Sci. Plant Anal. 10:1371-1380.

Uriu, K. 1964. Effect of postharvest soil moisture depletion on subsequent yield of apricots. Proc. Amer. Soc. Hort. Sci. 84:93-97.

Welker, W.V. and D.M. Glenn. 1989. Sod proximity influences the growth and yield of young peach trees. J. Amer. Soc. Hort. Sci. 114:856 859. 